\title{
Imaging of subsurface lineaments in the southwestern part of the Thrace Basin from gravity data
}

\author{
D. Aydogan ${ }^{1}$, A. Pinar ${ }^{2}$, A. Elmas ${ }^{3}$, O. Tarhan Bal ${ }^{1}$, and S. Yuksel ${ }^{4}$ \\ ${ }^{1}$ Department of Geophysics, Engineering Faculty, Istanbul University, 34320, Avcilar, Istanbul, Turkey \\ ${ }^{2}$ Kandilli Observatory and Earthquake Research Institute, Bogazici University, Cengelkoy, Istanbul, Turkey \\ ${ }^{3}$ Department of Geology, Engineering Faculty, Istanbul University, 34320, Avcilar, Istanbul, Turkey \\ ${ }^{4}$ Turkish Petroleum Corporation, 06100, Çankaya, Ankara, Turkey
}

(Received March 25, 2012; Revised August 27, 2012; Accepted August 27, 2012; Online published May 7, 2013)

\begin{abstract}
Linear anomalies, as an indicator of the structural features of some geological bodies, are very important for the interpretation of gravity and magnetic data. In this study, an image processing technique known as the Hough transform (HT) algorithm is described for determining invisible boundaries and extensions in gravity anomaly maps. The Hough function implements the Hough transform used to extract straight lines or circles within twodimensional potential field images. It is defined as image and Hough space. In the Hough domain, this function transforms each nonzero point in the parameter domain to a sinusoid. In the image space, each point in the Hough space is transformed to a straight line or circle. Lineaments are depicted from these straight lines which are transformed in the image domain. An application of the Hough transform to the Bouguer anomaly map of the southwestern part of the Thrace Basin, NW Turkey, shows the effectiveness of the proposed approach. Based on geological data and gravity data, the structural features in the southwestern part of the Thrace Basin are investigated by applying the proposed approach and the Blakely and Simpson method. Lineaments identified by these approaches are generally in good accordance with previously-mapped surface faults.
\end{abstract}

Key words: Gravity, Hough transforms, lineaments, faults, Thrace basin, Turkey.

\section{Introduction}

The Thrace Basin in northwestern Turkey (Fig. 1(a)), is a triangular-shaped Cenozoic depression (Doust and Arıkan, 1974; Keskin, 1974; Turgut et al., 1983) whose sedimentary fill in the centre of the basin reaches up to 9000 meters in thickness (Kopp et al., 1969; Turgut et al., 1991; Siyako and Huvaz, 2007). The Thrace Basin, between the Strandja Massif to the north and the Biga Peninsula to the south, constitutes one of the most important hydrocarbon provinces of Turkey, favorable particularly for natural-gas exploration. The regional geology of SW Turkish Thrace has been studied by various workers (e.g. Ternek, 1949; Boer, 1954; Andrews, 1960; Beer and Wright, 1960; Kopp et al., 1969; Görür and Okay, 1996; Tüysüz et al., 1998; Sakınç et al., 1999; Kaymakçı et al., 2007; Elmas, 2012 and references therein). In most of the published studies, particular attention was concentrated on paleontology, stratigraphy and reservoir features. Several studies encompassing geophysical methods have been carried out in NW Turkey and are available in the literature (e.g. Perinçek, 1991; Turgut et al., 1991; Ilkışık, 1995; Ateş et al., 2003, 2008, 2009). However, no detailed geological map, or knowledge of the structural elements of the southwestern part of the Thrace Basin is available, and also the subsurface geometry of the geolog-

Copyright (c) The Society of Geomagnetism and Earth, Planetary and Space Sciences (SGEPSS); The Seismological Society of Japan; The Volcanological Society of Japan; The Geodetic Society of Japan; The Japanese Society for Planetary Sciences; TERRAPUB.

doi:10.5047/eps.2012.08.014 ical units remains unsolved. In the southwestern part of the Thrace Basin, the first detailed geological map (Fig. 1(b)), including structural elements, was produced by Elmas et al. (2008). Furthermore, the area has not received a systematic regional geophysical interpretation and little is known about the subsurface geometry of the contact between the Paleogene and Neogene units at depth.

Geophysicists usually deal with lineaments as an indicator of a fault, boundary or any tectonic feature beneath the surface for the interpretation of gravity and magnetic anomaly maps. The basic features used to interpret the fault structures in those maps are the locations of gradient zones (Li et al., 1986; Illingworth and Kittler, 1988; Princen et al., 1990; Wang and Howarth, 1990; Mirmehdi et al., 1991; Karnieli et al., 1996; Lyngsie et al., 2006).

The linear variation fields and their parameters play an important role in map assessments. An experienced interpreter can easily recognize the zones of smooth linear changes. Due to certain geological conditions, however, it is not always easy to notice them in gravity and magnetic anomaly maps. In such cases, one may need an approach to enhance the lineaments. To obviate such problems, directional derivative and anomaly separation are the classical approaches. The first stage in lineament identification is usually the image enhancement and boundary detection processes applied to the digitized input images.

Gravity and magnetic survey methods are effectively used in basic geological studies, geothermal investigations, and engineering applications. Ilkışık (1980) explored the 


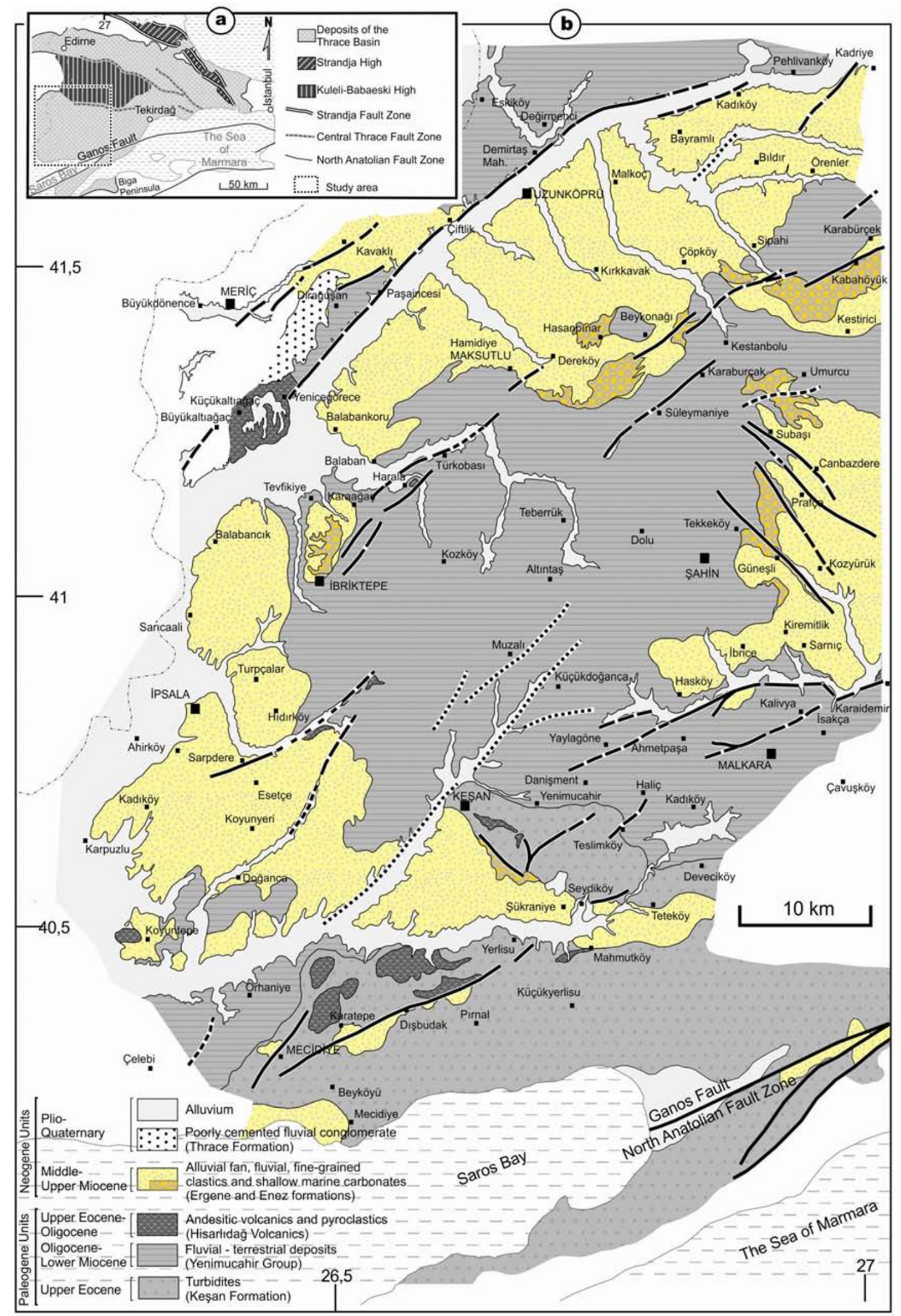

Fig. 1. (a) Map indicating the location of the study area (from Elmas, 2012). (b) Geology and tectonics map of the southwestern part of the Thrace Basin (from Elmas et al., 2008). Coordinates are in degrees.

crustal structure of the Thrace Basin using electromagnetic heat flow values beneath the basin and a crustal thickness methods. Çaglar (1999), assessing an E-W trending magnetotelluric profile data crossing the center of the basin, and heat flow data acquired from nearby wells, obtained low varying between $28-32 \mathrm{~km}$. Coşkun (2000) and Siyako and Huvaz (2007) investigated the tectonic structures of the region using seismic methods and well-logging data. Bayrak 
et al. (2004, 2006) explored the crust and upper mantle, highlighting the high-resistivity values of the Istranca Massif lying in the depth range 2.5 to $35 \mathrm{~km}$. Şenel (2005) obtained two distinctive depths of the basin by inverting the gravity anomaly data. Bayrak et al. (2006), evaluating the electromagnetic data measured at Thrace Basin, lay emphasis on the point that the northeast part of the basin has more complicated structures than the southeast part. They also drew attention to the normal faults parallel to the basin occurring at the boundary of the Istranca Massive, and the structural uplift toward Saros Bay in the southwest part of the Thrace Basin. Huvaz et al. (2007) comparing the geological and thermal features of the basin concluded that the thermal anomalies are the results of a basin evolution process.

Image processing tools in geology and geophysics are frequently used to identify tectonic structures as faults, widely-distributed fractures, etc. Generally, the lineaments are visually inspected by experienced interpreters, or can be automatically inferred using formulae incorporating criteria for lineament identification (Wiladis, 1999).

Image enhancement techniques are broadly applied to geophysical images that make them convenient for visual inspection and to understanding their geological significance. The frequently-used enhancement techniques are contrast healing, border fixing, and filtering (Zhang et al., 2005). Examples of border fixing related studies are Aydogan (2007, 2008, 2011), Blakely and Simpson (1986), Dolmaz et al. (2008), Elitok and Dolmaz (2008), McGrath (1991), Mallat and Zhong (1992), Moreau et al. (1997), Oruç and Keskinsezer (2008), Oruç and Selim (2011), Trompat et al. (2003). The most classical methods in geophysics are the approaches based on derivative calculations. The upward continuation methods are used to separate long and short wavelength anomalies (Fedi et al., 2012). A tilt filter introduced by Miller and Singh (1994) was used by Verduzco et al. (2004) to improve weak and strong anomalies. Yunxuan (1992) used the Radon transform method along with the continuation techniques to remove undesirable lineaments located in the synthetic gravity anomaly maps. The Radon transform was employed by Pawlowski (1997) and Zhang et al. $(2005,2006)$ to improve the potential field anomalies and position the lineaments. Kudo et al. (2004) developed a statistical method to investigate the spatial distribution of topographic lineaments by employing the Bouguer anomaly standard deviation as an index of gravity anomaly roughness. Their study focuses on the relationship between the complexity of gravity anomalies and the distribution pattern of topographic lineaments.

The initial application of the Hough transform method has been limited to binary border images. Then, in addition to the straight lines, it was used to establish analytical shapes such as circles and ellipses in the $2 \mathrm{D}$ images. The basic principle employed to detect such analytical shapes is similar to the one used to determine straight lines, and is based on the directional structuring between the parameter definition in the Hough space and the border points in the image space. Later, the method was generalized to draw points located on a line at distances which depend on a $\theta$ (in degrees) parameter, instead of drawing a point at a fixed distance in a parameter plane.

In this study, we use the Hough transform algorithm based on the upward continuation method to detect lineaments in gravity anomaly maps in order to better understand the tectonic evolution of the southwestern part of the Thrace Basin. Firstly, the borders of buried bodies, and the associated lineaments, are automatically depicted applying the methods described above to the gravity data. Secondly, taking into consideration the geological studies carried out in the region, the lineaments belonging to a common fault are merged for a possible tectonic interpretation of the thus determined structural features.

\section{Theory and Method}

\subsection{Extraction of lineaments based on image enhance-} ment techniques

Although quantitative modeling and inversion processes are quite recent and up-to-date techniques, qualitative geological interpretation of gravity and magnetic data are also carried out by visual inspection and image enhancement algorithms. The images derived from gravity and magnetic data through automatic image enhancement methods contribute to mapping the tectonic units. These maps depict the homogenous zones of high, or low, density/susceptibility separated from each other by discontinuities. The most important problem that we face in geophysical studies is the detection of the geometry of the bodies or faults fitting at different depths reflecting different geological conditions. Gravity and magnetic methods are the classical tools to identify such structures. Large faults, with huge vertical displacements, can be determined from the gradient zones in the gravity and magnetic maps. These are, in a regional scale, denoted as primary faults and can easily be noticed in the maps. Whereas, it is important to identify the faults which are difficult to notice in the anomaly maps, and which generate local gradient zones that are masked by large mass anomalies. Enhancement processes are applied to maps to determine the anomalies of such faults (Zeng et al., 1994; Aydogan, 2011). Several image enhancement techniques applied to potential field data have been developed for a qualitative and quantitative interpretation of fault model anomalies hidden by regional fields. Image processing is an operation to improve the quality of a digital image.

Here, the relation between tectonic and geologic elements is investigated through the identification of the lineament direction using gravity and magnetic anomaly maps. The lineaments are fixed using the image enhancement techniques such as HT, upward continuation and border analysis.

In addition to the faults detected in previous studies, we have determined new overburden faults from the potential field data. The Hough transform algorithm is a method that is mostly used for automatic border detection in a modelbased numerical image processing. In model-based methods, an image pixel alone is meaningless; but, assessing them by including nearby ones ascribe them significance. In general, the Hough method is based on a selection of the likely geometrical shapes in an image where the borders are fixed. Although it was first introduced by Hough (1962) to depict lineaments from black and white images, it was 

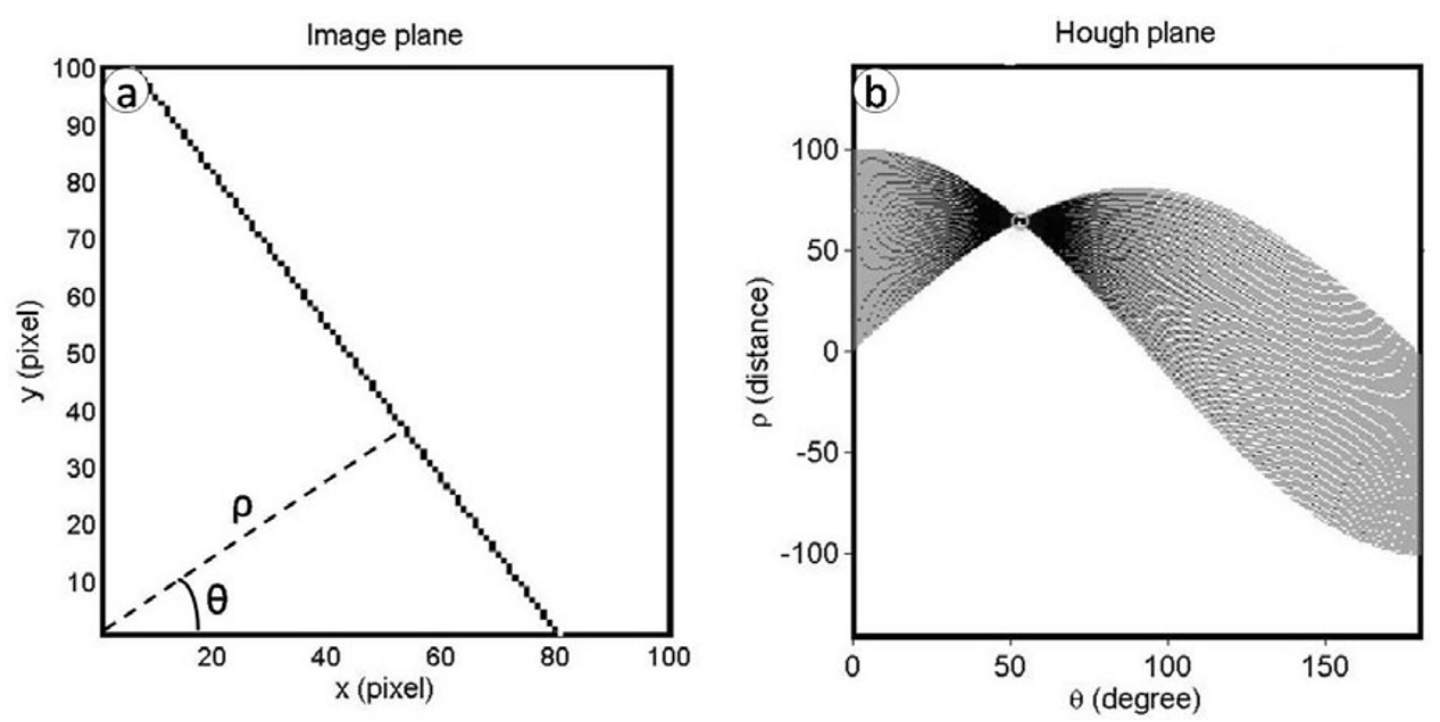

Fig. 2. Parameters of the Hough transform in (a) the image plane, and (b) the Hough transform plane.

later improved by Duda and Hart (1972) to detect different shapes in the images. The transformation allows all the line sets in an image plane to be represented in a dual Hough parameter plane by the intersection points of sinusoid curve sets.

The pixel sets located on the same line in the image plane are fixed to appear as peaks in the parameter plane and, by mapping those pixels, the method enables the detection of the edge pixel sets in the image. The main advantage of the Hough transform is that it is relatively unaffected by gaps in lines and by noise. The problem becomes one of finding the local maxima in the accumulator matrix. These local maxima must be higher than a certain threshold to extract long lines only, and short segments are removed. The threshold can be selected according to visual judgment. It is adopted to apply the upward continuation technique as a tool of regional/residual separation in order to investigate the orientation of subsurface structures. The Hough function converts each non-zero point in an image to a sinusoid in the parameter space (Fig. 2(b)). In the reverse case, each point in a parameter space corresponds to a straight line in the image space (Fig. 2(a)). The classical transformation is the determination of the lines from the input images. The definition of a line in the parameter space is given by Duda and Hart (1972) as:

$$
H(\rho, \theta)=\int_{-\infty}^{\infty} \int_{-\infty}^{\infty} f(x, y) \delta(\rho-x \cos \theta-y \sin \theta) d x d y
$$

where the $f(x, y)$ function is the binary input image and $\delta$ is the impulse response function. Here, if the dimension of the $f(x, y)$ input image in the image plane is $m \times n$, assuming the sampling rate of the points in the $x$ and $y$ direction in the input image to be $\Delta x$ and $\Delta y$, and the upward continuation function as $F(x, y)$, then the Hough equation becomes:

$H(\rho, \theta)=\sum_{m} \sum_{n} F(m, n) \delta(\rho-m \Delta x \cos \theta-n \Delta y \sin \theta)$.
The impulse response function contributes, in the conversion of each point of the input image, to a sinusoid in a parameter space using the equation:

$$
\rho=m \Delta x \cos \theta+n \Delta y \sin \theta .
$$

The determination of the lineaments utilizing the Hough transformation has been employed successfully in various fields. The principal advantage of the method is being not so sensitive to the noise in the images and the gaps along the lines. Details concerning the method can be found in Wang and Howarth (1990), Capineri et al. (1998), Fitton and Cox (1998), Zhang et al. (2005, 2006), Cooper (2006), and Aydogan (2008, 2011).

Here, we use the HT algorithm in conjunction with upward continuation to establish subsurface discontinuities. The block diagram of the algorithm is portrayed in Fig. 3. The upward continuation is applied to the input data given in Eq. (2) in order to image the lineaments resulting from the effects of the bodies at different depths. Such an employment of the transformation provides an instrument for the interpretation of the local and global data sets. We also applied the boundary analysis algorithm (Blakely and Simpson, 1986) to the Bouguer anomaly map to evaluate the performance of the HT technique. The method was firstly introduced by Cordell and Grausch $(1982,1985)$ for the estimation of the borders of magnetic bodies; later, the method was improved by Blakely and Simpson (1986) for the fast interpretation of the intensity of horizontal gradients. The horizontal gradients of the gravity anomalies of different masses are calculated. The maxima of the horizontal gradients are estimated from the eight neighboring points of a grid point by comparing the horizontal, vertical and diagonal elements. Using a threshold value of 20.55, estimated as half of the difference between the maximum and minimum Bouger anomaly values, the 5-pixel-long lineaments, and longer ones, are automatically determined in the accumulator matrix. 

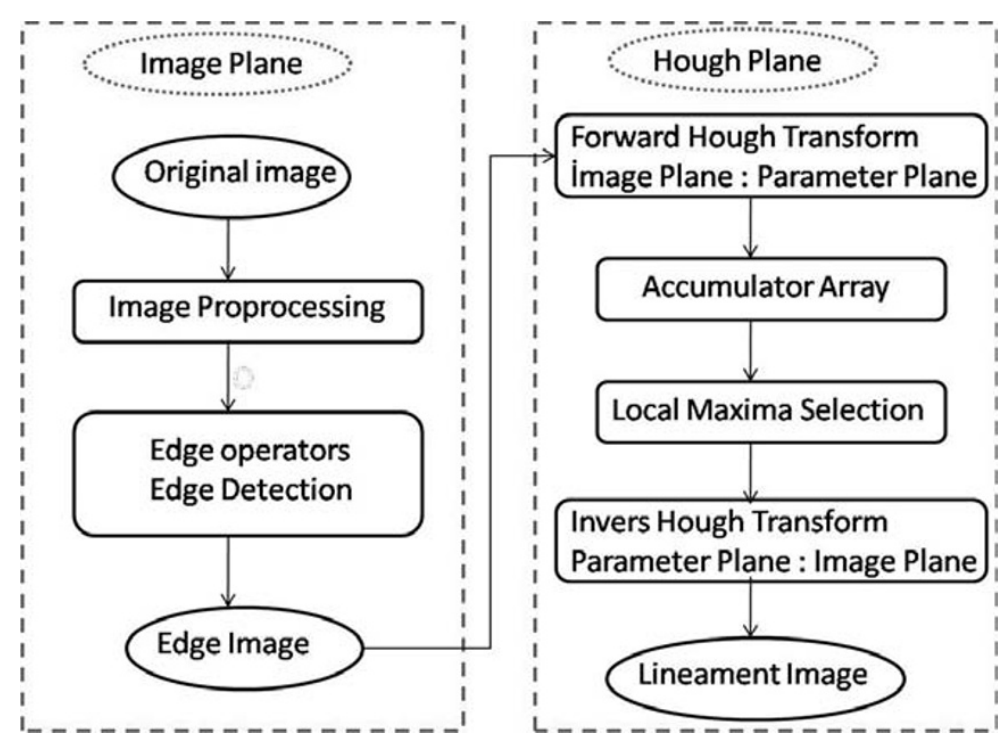

Fig. 3. Flowcharts of the procedure used in automatic lineament extraction by the Hough transform.

\section{Geological Setting}

The study area is located in the southwestern part of the Thrace Basin in northwestern Turkey (Fig. 1(a)). It is bounded to the south by the Aegean Sea, a segment of the North Anatolian Fault, the Ganos Fault (Şengör, 1979), and to the west by the metamorphic rocks of the Rhodope Massif in Greece. To the north and east, the widespread Upper Miocene-Quaternary deposits of the Thrace Basin exist.

\subsection{Pre-Neogene units of southwestern Thrace}

The oldest rocks to the north of the Gulf of Saros, which crop out in a very small area around Mecidiye, consist of highly-altered low-grade metaclastic rocks (Elmas, 2012) showing a great similarity to the Triassic metamorphic rocks of the Strandja Massif (Okay et al., 2010). Furthermore, the hydrocarbon exploration wells around the Keşan to the north of the Ganos Fault (Figs. 1(a) and (b)) penetrated into similar metamorphic rocks below the Tertiary basin fill suggesting that the Strandja-type basement is continuous from north to south (Siyako and Huvaz, 2007).

The Paleogene sequence begins with 50-m-thick coarsegrained clastics deposited unconformably on the metamorphic rocks of the Strandja Massif. The clastic sequence passes upwards into the Upper Eocene (Özcan et al., 2010) limestone of the Soğucak formation. To the east, the lowermost sedimentary unit within the Paleogene sedimentary succession is the Gaziköy Formation (Sümengen and Terlemez, 1991) consisting of shales, siltstones, sandstones, and it also contains acidic tuff levels. The unit is bounded by the Ganos Fault to the south. The Soğucak Formation in the west, and the Gaziköy Formation in the east, are conformably overlain by the Upper Eocene (Sümengen et al., 1987; Y1ld1z et al., 1997) turbiditic deposits of the Keşan Formation. These deposits interfinger with the andesiticdacitic lavas and pyroclastics forming a magmatic complex in the north of the Gulf of Saros (Fig. 1(b)) reaching up to 800-m thickness. Radiometric data indicate a $35 \pm 0: 9 \mathrm{Ma}$ (K/Ar, Sümengen et al., 1987) age for this complex. The turbiditic deposits pass gradually upwards and northwards into marginal marine and continental sandstones-shales (the Mezardere, Osmancık and Danişment formations and the Yenimucahir Group (Ünal, 1967)). The ages of these sediments, which form the uppermost strata of the sequence of the Thrace Paleogene Basin, extend from Oligocene to Early Miocene (Siyako, 2006). In all previous studies, the contact between the Paleogene and Neogene sequences was interpreted as an angular unconformity throughout the basin. However, Elmas et al. (2008) suggested that the contact between the Paleogene and Neogene series is tectonic in many places in the area between the Ergene River and Saros Bay.

\subsection{Neogene deposits of southwestern Thrace}

The Neogene sequences display many different facies associations because of their environments of deposition. The sequences have been lithostratigraphically divided as the Enez, Ergene and Thrace formations.

The oldest Neogene strata are the Middle-Upper Miocene lacustrine and shallow marine deposits to the southwestern part of the study area, and have been designated by Kasar et al. (1983) as the Enez Formation. Around Ipsala and Ibriktepe, on the Paleogene units, the sequence begins with fresh- and brackish-water shallow marine clastics and carbonates. They gradually pass into clays and weaklycemented, cross-bedded sandstones. The deposits of the Middle-Upper Miocene (Sümengen et al., 1987; Şentürk and Karaköse, 1987) Enez Formation, which indicate a mixed (clastic and carbonate) marginal marine environment for the deposition (Elmas et al., 2008), are overlain by the cross-bedded yellow sandstones and conglomerates of the Ergene Formation with an erosional contact.

To the southwestern part of the Thrace Basin, the Ergene Formation (Holmes, 1961) begins with different stratigraphic units on the deposits of the Enez Formation and the Paleogene basement units. South of Pehlivanköy, east of Ipsala and Meriç (Fig. 2(b)), the Ergene Formation starts with carbonate, carbonate-cemented sandstones and continues with weakly-cemented and cross-bedded sandstones containing lensoidal channel-fill conglomerates. Also, south 
of Çöpköy and Dereköy, and around İbriktepe (Fig. 2(b)), the succession begins with coarse conglomerates. In many places, the conglomerates contain blocks of metamorphic rocks and Paleogene sandy limestone. The blocks range in size from 5 to $70 \mathrm{~cm}$ and are embedded in a pebblysandy matrix. The blocky deposits of the Ergene Formation, which are located in close proximity to NE-trending faults (Fig. 2(b)), are interpreted as fan deposits with associated river channel fills (Elmas et al., 2008). Similar units are also observed in the east and south of the study area to the north of Malkara and south of Keşan (Fig. 2(b)). The blocky deposits pass upward into a sequence of fine sandstone, siltstone, clayey limestone and marl. Mammal fauna, collected from several parts of the sequence, indicates a Late Miocene age (Ünay and de Bruijn, 1984; Umut et al., 1984).

The Thrace Formation (Umut et al., 1983) unconformably overlies the Upper Miocene Ergene Formation and Paleogene units (Fig. 2(b)). The formation consists of fluviatile clastics approximately $20-\mathrm{m}$ thick. The clastics crop out mainly to the north of the Ergene River and no fossil remains have been found in these deposits. From the stratigraphical point of view, the age span of the formation should be Plio-Quaternary (Sakınç et al., 1999).

\subsection{Structural elements in southwestern Thrace}

Due to extensive Upper Miocene and younger cover units, most of the knowledge on the structural features of the Thrace Basin, collected by Perinçek (1991), Doust and Arıkan (1974), Burke and Uğurtaş (1974), Turgut et al. (1991), Okay et al. (2000), Turgut and Eseler (2000), Coşkun (2000), are from seismic studies and borehole data. These data indicate that there is an E-W trending buried high area (Kuleli-Babaeski Highland, Keskin, 1974; Çoşkun, 2000) under the Late Miocene cover sediments in the central part of the Thrace Basin (Fig. 1(a)). Westwards from the area of uplift, the crystalline rocks of the Rhodope massif are exposed in eastern Greece. The high has been overlain by the deposits of the Thrace Paleogene Basin since the end of Eocene (Doust and Arıkan, 1974), or Early Oligocene (Keskin, 1974), times. To the north, the high is bounded by branches of the WNW-ESE-trending rightlateral strike-slip Central Thrace Fault Zone (Elmas, 2012). To the south, in the area to the northwest of Tekirda $\breve{g}$, the existence of another fault is observed on the magnetotelluric profile of Bayrak et al. (2004). The fault, which is overlain by the Late Neogene-Quaternary deposits of the basin (Burke et al., 1974), and has mainly a south-verging thrust component (Perinçek, 1991), is evaluated as a southern fault system on the Central Thrace strike-slip fault zone (Elmas, 2003, 2012, Fig. 1(a)). On the seismic profiles of Burke et al. (1974), the Central Thrace strike-slip faults cut through the Eocene-Miocene sedimentary succession (Perinçek, 1991; Turgut et al., 1991) of the Thrace Paleogene Basin, and are overlain by the Upper Miocene (Ünay and de Bruijn, 1984) deposits of the Thrace Neogene Basin.

Another already-known structural element is the Ganos Fault (Şengör, 1979) located to the southern part of the basin, constituting a segment of the active and dextral North Anatolian Fault Zone (Ketin, 1969; Jackson and McKenzie, 1988; Barka, 1992). The fault caused intense uplift and deformation of the Neogene, and older, sedimentary strata on the southern margin of the basin (Şengör et al., 1985; Turgut et al., 1991; Okay et al., 2004).

In addition to these structural elements, in southwestern Thrace there are two distinct groups of faults, which are described for the first time by Elmas et al. (2008). The geological structure of southwestern Thrace is dominated by NE-trending faults (Fig. 1(b)). In the eastern central part of the area, the second group faults have a NW trend. The Neogene deposits of the Ergene Formation overlie all the older series with a distinct erosional unconformity of basinwide extent. But, at some locations, the contact between the Neogene and Paleogene deposits is defined by NE-trending faults (Fig. 1(b)). These faults have controlled the deposition of Upper Miocene alluvial fans and fluvial deposits in the lower part of the Ergene Formation. Also the NWtrending faults cut and deform the Neogene sedimentary rocks of the Ergene Formation (Elmas et al., 2008).

\section{Data and Results}

\subsection{Lineaments extraction from potential field data}

The southwestern part of the Thrace Basin in Turkey is selected as a study area to demonstrate the capabilities of the Hough transform algorithm for lineaments extraction. The Hough transform algorithm is a powerful tool against noise, since the possibility of noise data points making a contribution to a peak in the parameter space is quite low. The noise affects the general level of the accumulator matrix, but not the local maxima. Depending on the number of peaks in the parameter space, the structures with different geometrical shapes in a data set can be identified by the Hough transform technique. The disadvantage of the method is the need for large dimensions and timeconsuming calculations.

We obtained the high-resolution potential field data from the Turkish Petroleum Anonymous Organization (TPAO) and applied the method described in this study. Figure 4 illustrates the Bouguer anomaly map that has a grid spacing of $1 \times 1 \mathrm{~km}$ and consists of 14664 gravity measurements. This map consists of a number of short-wavelength residual anomalies that reflect shallow sources superposed on longwavelength regional anomalies that reflect deeper sources. This map shows strong high positive anomalies which were accompanied by the extrusion of abundant volcanic rocks in the southern part of the study area (Figs. 1(b) and 4). Low Bouguer anomalies in the northwestern and central parts are associated with the Neogene deposits. GRH and GRL represent the highest, and lowest, gravity values, respectively (Fig. 4). In the study area, the Bouguer anomaly values range from $15 \mathrm{mGal}$ in the north, to $68 \mathrm{mGal}$ in the south, with many short- and long-wavelength anomalies reflecting the complicated tectonic history. The Bouguer gravity anomaly is used as the input data to the proposed algorithm for determining geological boundaries that are difficult to identify in the study area. Upward continuation of the Bouguer gravity anomalies can be used to separate the gravity field into geologically-relevant components arising from subsurface features seated at different depths and sizes. This is the well-known regional residual separation problem of gravity studies.

The gravity anomaly map, which presents the main geo- 


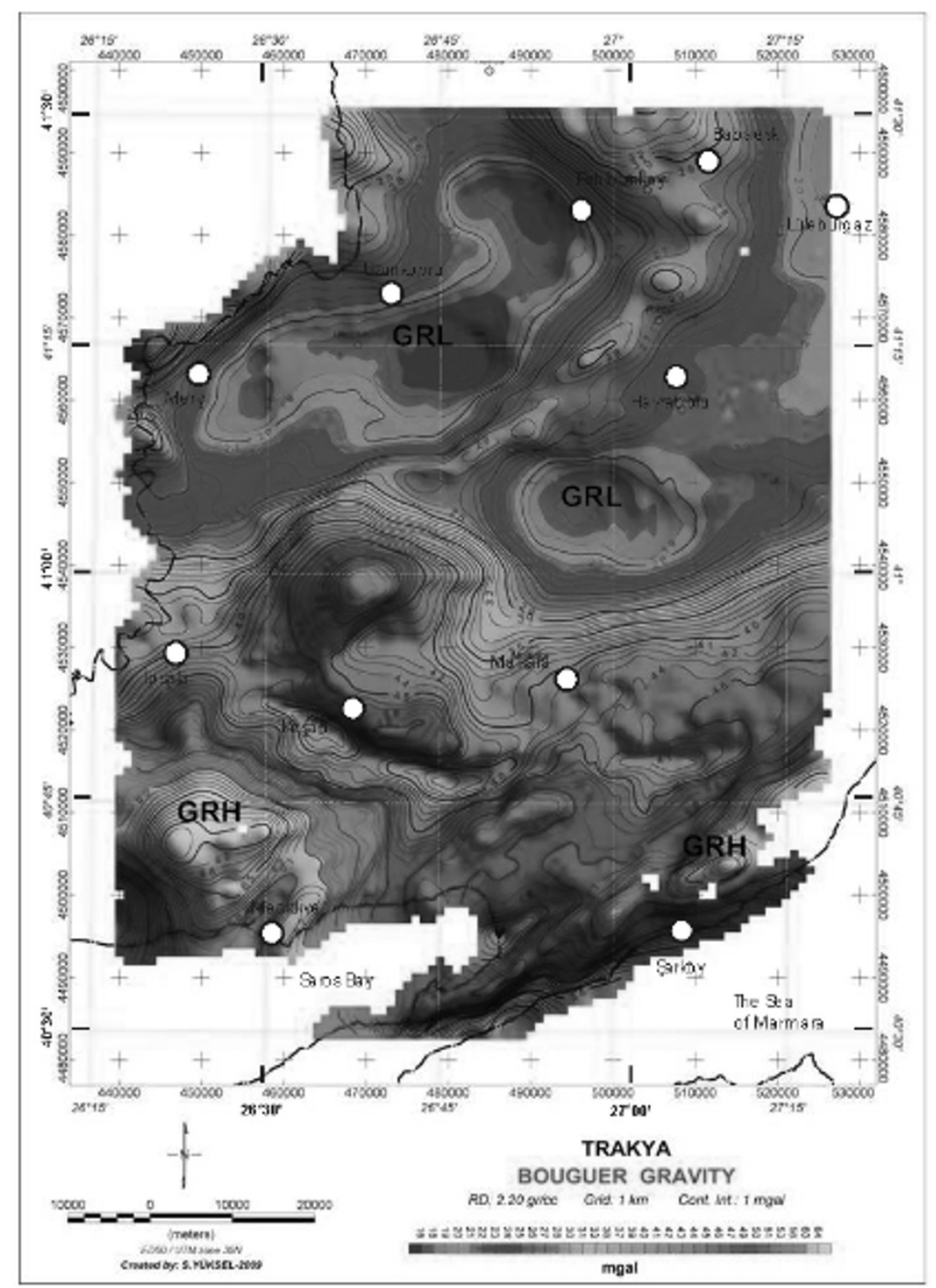

Fig. 4. Bouguer anomaly map of southwestern part of the Thrace Basin, Turkey. The map covers $112 \times 85 \mathrm{~km}$, and gravity values range from 15 $\mathrm{mGal}$ to $68 \mathrm{mGal}$. The contour interval is $1 \mathrm{mGal}$, and the grid interval is $1 \mathrm{~km}$. GRH and GRL denote the maximum and minimum gravity regions, respectively. Coordinates are in kilometers and degrees.

physical data, is used to identify lineaments. We utilize the upward continuation map which is applied to the Bouger anomaly map to identify the effects of the bodies at different depths and dimensions to constrain better the likely fault systems. In this study, HT is used to extract lineaments after upward continuation of the Bouguer gravity data to $5 \mathrm{~km}$. With the Hough transform, the lineaments (SL) obtained from the surface gravity values (Bouger anomaly map) are superimposed with the lineaments (SSL) obtained from the 5-km-upward continuation map to check whether the structures extend deeper in the crust. Also, taking into consideration the previous studies, the lineaments are determined manually (ML). In the northern part of the study area the ML1, in the central part ML7, in the southern part ML5, ML8, and ML9, lineaments are found to extend from the surface to the deeper part downward, but the rest of the lineaments continue partially downward.

Applying to the HT of the Bouguer anomaly, and to the upward continued data, the surface and subsurface lineaments are obtained and the resulting map is shown in Fig. 5. This map shows lineaments which are surface and subsurface superimposed on the Bouguer anomaly map. It is observed from this map that the proposed algorithm can detect major and minor lineaments, but some false lineaments are also detected, especially in the northern and central parts of the study area. Lineaments are described by an appropriate level of pixel values: a process known as thresholding. In general, a threshold value can be designated in two ways. One way is from a few known structures in the area, or from an available tectonic map. It may also be determined by a professional opinion. To some extent, this latter way introduces subjectivity into the mapping process. It is observed that with a high threshold value, the effects with a long wavelength in the Bouguer anomaly maps are completely lost, while erroneous lineaments are produced with a low threshold value. In order to obtain the desired details, 


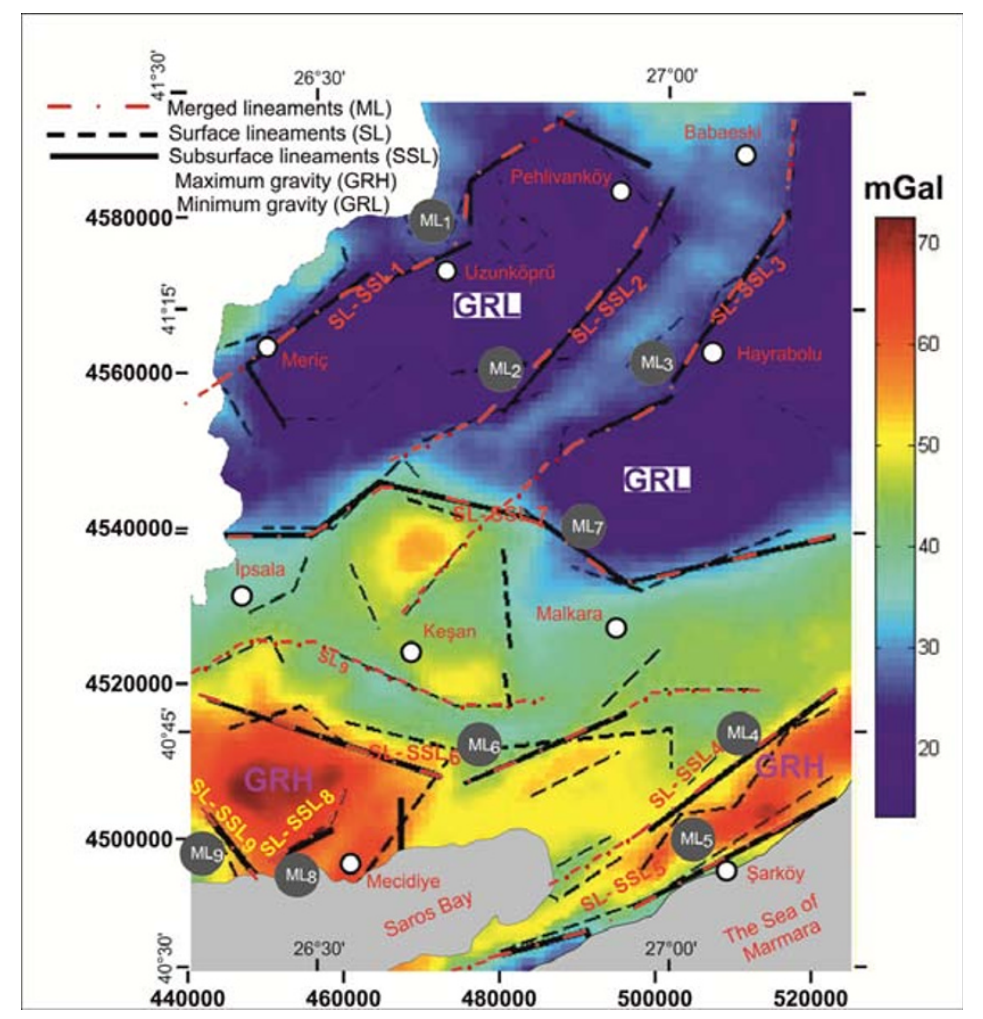

Fig. 5. Lineament map of the southwestern part of the Thrace Basin (Turkey) obtained from the Hough transform algorithm. The automatically-extracted surface lineaments (dashed line) and subsurface lineaments (solid line) from upward continuation of the Bouguer gravity data to $5 \mathrm{~km}$ are superimposed on the Bouguer anomaly map of the study area shown in Fig. 4. GRH and GRL denote the maximum and minimum gravity regions, respectively. SL: the lineaments retrieved from the Bouger anomaly map, SSL: the lineaments estimated from the upward continuation map, ML: the shallow and deep lineaments that are merged manually combining the SL and SSL. Coordinates are in kilometers and degrees.

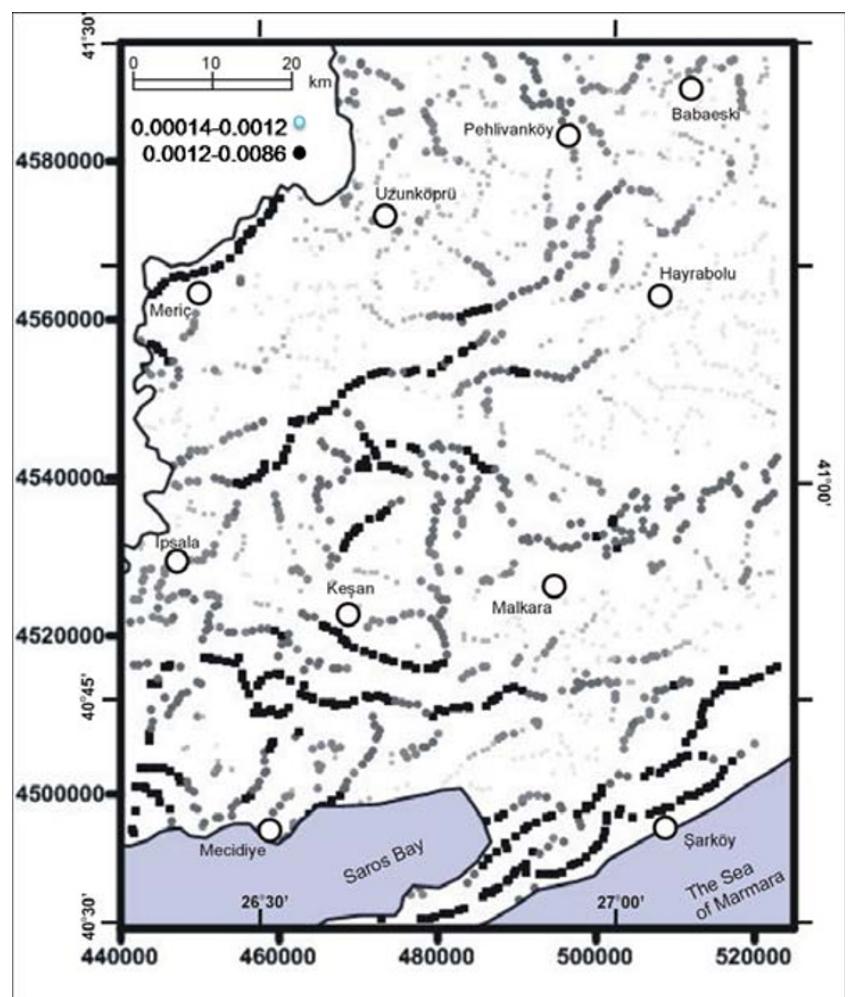

Fig. 6. Boundary map of the study area obtained from the boundaries analysis algorithm (Blakely and Simpson, 1986). Coordinates are in kilometers and degrees. 
the threshold value can be adjusted accordingly (Aydogan, 2011). This map clearly shows that both major lineaments having a large vertical displacement, and minor lineaments that are not obvious in the Bouguer anomaly map, are well defined using the Hough transform approach. The lineaments identified by HT are related to subsurface sources due to its large lateral extent over the whole southwestern Thrace Basin area. We also apply one of the classical boundary detection algorithms (Blakely and Simpson, 1986) to the Bouger anomaly map (Fig. 4) and the output map is shown in Fig. 6. This map provides auxiliary information for the interpretation of lineaments. The proposed algorithm, and the classical method, yield similar results (Figs. 5 and 6). Most of the geological features can be visually shown to fit in with our results. North-south- and east-west-trending lineaments in the study area are clearly imaged.

In the study area, 9 main lineaments systems are identified after merging several major and minor lineaments into a single lineament (Fig. 5). SL stands for the lineaments that are automatically obtained by applying the Hough transform to the Bouger anomaly map. SSL shows the lineaments that are obtained from the upward continuation map (the regional effects). ML depicts the lineaments defined from the residual and regional effects which are manually merged by considering geological and geophysical knowledge obtained from previous studies. According to defined lineament systems, SL and SSL stand for surface and subsurface lineaments, respectively. SL-SSL ${ }_{1}-\mathrm{SL}_{-} \mathrm{SSL}_{9}$ lineaments which appeared in the gravity anomaly map as a gradient zone geologically belong to the single lineament systems $\left(\mathrm{ML}_{1}-\mathrm{ML}_{9}\right)$. Here, ML stands for merged SL-SSL lineaments.

We identify three characteristic types of lineaments. One of these types is NNE-SSW-trending lineaments located at the northern part of the study area denoted $\mathrm{ML}_{1}, \mathrm{ML}_{2}$ and $\mathrm{ML}_{3}$. In the same way, those located at the southern part of the area are denoted as $\mathrm{ML}_{4}, \mathrm{ML}_{5}$ and $\mathrm{ML}_{8}$. Others are nearly E-W-trending lineaments located at the central part of the study area denoted as $\mathrm{ML}_{6}$ and $\mathrm{ML}_{7}$. In this region, the lineament denoted as $\mathrm{SL}_{9}$ is also seen on the boundary map (Fig. 6). Finally, an NNW-SSE-trending lineament located in the southwestern part of the study area is denoted as $\mathrm{ML}_{9}$. While $\mathrm{ML}_{1}$ and $\mathrm{ML}_{3}$ lineaments that extend to the west of Uzunköprü and Hayrabolu, respectively, are not clearly seen in Fig. 6. $\mathrm{ML}_{2}, \mathrm{ML}_{3}, \mathrm{ML}_{6}$ and $\mathrm{ML}_{7}$ lineaments are particularly seen in Fig. 1(b).

The geological map (Fig. 1(b)), the Bouguer anomaly map (Fig. 4), The lineament map (Fig. 5) and the boundary map (Fig. 6), are integrated to provide evidence of the determination of the likely lineament systems. Analysis of these maps leads us to a comprehensive understanding of the system of faults of the study area. ML1, ML2, ML3, ML7, SL9, SL-SSL8 lineaments, in the lineament and boundary maps (Figs. 5 and 6), overlap with faults in the geological map. Also the $\mathrm{ML}_{4}$ lineament between Şarköy and Malkara (Fig. 6) overlaps with the Ganos segment of the North Anatolian Fault.

\section{Conclusions}

This study presents the results of geophysical and geological surveys carried out as a part of integrated geophysical and geological studies in the southwestern part of the Thrace Basin. We describe how image enhancement techniques are applied to the potential field data, and how the Hough transformation is applied to data obtained from upward continuation. The method is convenient for the detection of lines in the parameter space. In this frame, the detection of major and minor lineaments is possible.

One of the objectives in the structural interpretation of the geophysical data is mapping the faults and fracture zones. These features are characterized by lines and curves and, thus, can be determined through a lineament interpretation of the processed potential field data. It is difficult to know which of the methods will yield more reasonable results for geological interpretation. In the ultimate decision regarding the analysis and image processing selection, not only experience, but also the shape of the anomalies and the convergence of the best fitting model, are important criteria.

We have applied the proposed method to the data acquired from the southwestern part of the Thrace basin located in NW, Turkey. During the geological interpretation stage, the adaptation of the method to the gravity data characteristics was examined. In this respect, the method is useful regarding automatic lineament detection in the gravity data and visual inspection of the results. Despite the traces of faults and contacts are not obviously identifiable from the Bouguer anomaly map, the proposed image enhancement technique successfully depicts the location of discontinuities.

In our lineament map (Fig. 5), it appears that the position of lineaments in the southwestern part of the Thrace Basin generally show a similarity with a previous map (Fig. 1(b)) prepared by Elmas et al. (2008) on the basis of a field study. In Fig. 5, the approximately E-Wtrending structural line north of İpsala and Malkara, determined from seismic studies, indicates the southern border of the Kuleli-Babaeski High. In addition, the faults around Meriç, Uzunköprü and Pehlivanköy can be observed both in the geological map (Fig. 1(b)) and in our lineament map (Fig. 5) as three NE-trending fault zones. In the area between Ipsala, Keşan and Saros Bay, the surface structural elements shown in Fig. 5 collide with those of the geological map (Fig. 1(b)). In this study, we determined ENE-WSW-extending fault systems, besides the NE-SWextending faults that were previously identified by the geological studies carried out in the region (Elmas et al., 2008). The NE-SW-trending faults ML1, ML2 and ML3, occurring in the northern part of Fig. 5, were detected by the proposed method. The surface expressions of the faults are obvious in the Bouger anomaly map, while their depth extensions are retrieved through the upward continuation analysis. In addition, as shown in the central part of Fig. 5, a NW-SE striking fault segment (ML7) is located to the north of the city Malkara along with a ENE-WSW striking fault line lying to the NE of the city. In the southern part of Fig. 5, we identified the well-known Ganos fault segment of the NAF (ML4) along with the newly-discovered ENE-WSWextending ML6 fault line. The ML5 fault line running par- 
allel to the Ganos fault segment was also one of the newlydetected faults during the present work. Consequently, by applying the proposed approach to a gravity anomaly map, a detailed general view of surface, and subsurface, structural features can be obtained successfully. The method is a tool that can contribute to the geophysical interpretation in determining fault traces, but the observations of experienced reviewers are needed to define the geological meaning of the geophysical results. Thus, the Hough transform algorithm can be considered to be a useful tool, among with other geophysical techniques, in the investigation of subsurface boundaries over wide areas.

Acknowledgments. The comments raised by the anonymous reviewer, and Prof. Dr. Takeshi Kudo, greatly improved the manuscript. We appreciate very much their help. The authors are grateful to the Turkish Petroleum Corporation (TPAO) for their kind permission to use gravity data of southwestern part of of the Thrace Basin from Turkey.

\section{References}

Andrews, D. C., Geological report of the balabancık-koru-ridge-keşanipsala-mecidiye region, Internal Report of Tidewater Oil Company, Petrol Dairesi, April 1960, Ankara, 1960.

Ateş, A., T. Kayıran, and I. Sincer, Structural interpretation of the marmara region, NW Turkey from aeromagnetic, seismic and gravity data, Tectonophysics, 367, 41-99, 2003.

Ateş, A., F. Bilim, A. Buyuksarac, and O. Bektas, A tectonic interpretation of the marmara sea, NW Turkey from geophysical data, Earth Planets Space, 60, 169-177, 2008.

Ateş, A., A. Büyüksaraç, F. Bilim, Ö. Bektaş, Ç. Şendur, and G. Komanovalı, Spatial correlation of the aeromagnetic anomalies and seismogenic faults in the Marmara region, NW Turkey, Tectonophysics, 478, 135-142, 2009.

Aydogan, D., Processing the bouguer anomaly map of biga and the surrounding area by the cellular neural network, Application to the southwestern marmara region, Earth Planets Space, 59, 201-208, 2007.

Aydogan, D., Extraction of lineaments from gravity anomaly maps by means of Hough transform, Application to central Anatolia, e-Journal of New World Sciences Academy, 3(4), 642-655, 2008.

Aydogan, D., Extraction of lineaments from gravity anomaly maps using the gradient calculation: Application to Central Anatolia, Earth Planets Space, 63, 903-913, 2011.

Barka, A. A., The north anatolian fault zone, Annales Tectonicae, 6, 164 195, 1992.

Bayrak, M., A. Gürer, and Ö. F. Gürer, Electromagnetic imaging of the Thrace Basin and Intra-Pontide subduction zone, Northwestern Turkey, Int. Geol. Rev., 46, 64-74, 2004.

Bayrak, M., A. Gürer, Ö. F. Gürer, O. M. Ilkısık, and A. T. Basokur, MohrCircle based rotational invariants of a magnetotelluric data set from the Thrace region of Turkey, Geological Implications, Turkish J. Earth Sci., 15, 95-110, 2006.

Beer, H. and J. A. Wright, Stratigraphy of the Ganosdag, Korudag and Kesan Hills District I (Thrace), TPAO Rap., 736, Boer, 1960.

Blakely, R. J. and R. W. Simpson, Approximating edges of source bodies from magnetic or gravity anomalies, Geophysics, 51, 1494-1498, 1986.

Boer, N. P. de, Report on geological reconnaissance in Turkish Thrace, G.A. Report, 25373, The Hague, Petrol Dairesi, 1954.

Burke, W. F. and G. Uğurtaş, Seismic interpretation of Thrace Basin, Proceedings of the 2nd Petroleum Congress of Turkey, Ankara, 227248, 1974.

Çaglar, I., Geothermal potential in Western Anatolia and its relationship between electrically conductive zones, Proceedings of XXIX Congress of International Association of hydrogeologists (IAH) in Slovak Republic, 665-670, 1999.

Capineri, L., P. Grande, and J. A. G. Temple, Advanced image processing technique for real time interpretation of ground penetrating radar images, Int. J. Imag. Syst. Technol., 9(1), 51-59, 1998.

Cooper, G. R. J., Geophysical applications of the Hough transform, S. Afr. J. Geol., 109, 555-560, 2006.

Cordell, L. and V. J. S. Grauch, Reconciliation of the discrete and integral
Fourier transform, Geophysics, 47(2), 237-343, 1982.

Cordell, L. and V. J. S. Grauch, Mapping basement magnetization zones from aeromagnetic data in the San Juan basin, New Mexico, edited by W. J. Hinze, The utility of the regional gravity and magnetic anomaly maps, Soc. Explor. Geophys., 181-197, 1985.

Coşkun, B., Influence of the Istranca-Rhodope massifs and strands of the North Anatolian Fault on oil potential of Thrace Basin, NW Turkey, $J$. Petrol. Sci. Eng., 27, 1-25, 2000.

Dolmaz, M. N., Ö. Elitok, and U. Y. Kalyoncuoglu, Interpretation of low seismicity in the Eastern Anatolian collisional zone using geophysical (seismicity and aeromagnetic) and geological data, Pure Appl. Geophys., 165, 311-330, 2008.

Doust, H. and Y. Arrkan, The geology of the Thrace Basin, Proceedings of the 2nd Petroleum Congress of Turke, Ankara, pp. 227-248, 1974.

Duda, R. O. and P. E. Hart, Use of the Hough transformation to detect lines and curves in pictures, Comm. ACM, 15, 11-15, 1972.

Elitok, Ö. and M. N. Dolmaz, Mantle flow-induced crustal thinning in the area between the easternmost part of the Anatolian plate and the Arabian Foreland (E Turkey) deduced from the geological and geophysical data, Gondwana Res., 13, 302-318, 2008.

Elmas, A., Late Cenozoic tectonics and stratigraphy of Northwestern Anatolia: the effects of the North Anatolian Fault to the region, Int. J. Earth Sci., 92, 380-396, 2003.

Elmas, A., The Thrace Basin, stratigraphic and tectonic-palaeogeographic evolution of the Palaeogene formations of northwest Turkey, Int. Geol. Rev., doi:10.1080/00206814.2011.644732, 2012.

Elmas, A., İ. Yılmaz, and E. Kırcı, GüneybatıTrakya'da Neojen-Erken Kuvaterner döneminde etkili olan yapısal özelliklerin araştırılması, The Scientific and Technical Research Council of Turkey, Ankara, Report no. 105Y299, p. 157, 2008.

Fedi, M., G. Florio, and L. Cascone, Multiscale analysis of potential fields by a ridge consistency criterion, the reconstruction of the Bishop basement, Geophys. J. Int., 188, 103-114, 2012.

Fitton, N. C. and S. J. D. Cox, Optimising the application of the Hough transform for automatic feature extraction from geoscientific images, Comput. Geosci., 24(10), 933-951, 1998.

Görür, N. and A. Okay, A fore-arc origin for the Thrace Basin, NW Turkey, Geologische Rundschau, 85, 662-668, 1996.

Holmes, A. W., A stratigraphic review of Thrace, TPAO Rap., 368, 1961.

Hough, P. V. C., Method and means for recognizing complex patterns, US Patent, 3069654, 1962.

Huvaz, O., N. Karahanoglu, and V. Ediger, The thermal gradient history of the Thrace Basin, NW Turkey Correlation with Basin Evolution Processes, J. Petrol. Geol., 30(1), 3-24, 2007.

Ilkışık, O. M., Trakya'da yerkabuğunun manyetotelurik yöntemle incelenmesi, Unpubl. Ph.D. thesis, Istanbul Technical University, Mining Faculty, 1980.

Ilkışık, O. M., Regional heat flow in Western Anatolia using silica temperature estimates from thermal springs, Tectonophysics, 244, 175-184, 1995.

Illingworth, J. and J. Kittler, A survey of the Hough transform, Comp. Vision Graph. Image Proc., 44, 87-116, 1988.

Jackson, J. and D. P. McKenzie, The relationship between plate motions and seismic moment tensors, and the rates of active deformation in the mediterranean and middle east, Geophys. J., 93, 45-73, 1988.

Karnieli, A., A. Meisels, L. Fisher, and Y. Arkin, Automatic extraction and evaluation of geological linear features from digital remote sensing data using a Hough transform, Photogramm. Eng. Rem. Sens., 62(5), 525531, 1996.

Kasar, S., K. Bürkan, M. Siyako, and O. Demir, Tekirdağ-Şarköy-KeşanEnez bölgesinin jeolojisi ve hidrokarbon olanakları, Turkish Petroleum Corporation, Report no. 1771, Ankara, 88 p., 1983 (in Turkish).

Kaymakçı, N., E. Aldanmaz, C. Langereis, T. L. Spell, Ö. F. Gürer, and K. A. Zanetti, Late miocene transcurrent tectonics in NW Turkey, Evidence from Palaeomagnetism and ${ }^{40} \mathrm{Ar}-{ }^{39} \mathrm{Ar}$ Dating of Alkaline Volcanic Rocks, Geol. Mag., 144(2), 379-392, 2007.

Keskin, C., The stratigraphy of the Northern Ergene Basin, Proceedings of the 2nd Petroleum Congress of Turkey, Ankara, pp. 137-163, 1974.

Ketin, I., About the North Anatolian Fault, Bull. Miner. Res. Explor. Inst. Turkey, 72, 1-29, 1969.

Kopp, K. O., N. Pavoni, and C. Schindler, Das Ergene Becken, Beihefte Zum Geologischen Jahrbuch, 76, 1-136, 1969.

Kudo, T., A. Yamamoto, T. Nohara, H. Kinoshita, and R. Shichi, Variations of gravity anomaly roughness in Chugoku district, Japan: Relationship with distributions of topographic lineaments, Earth Planets Space, 56, e5-e8, 2004. 
Li, H., M. A. Lavin, and R. J. McMaster, Fast Hough Transform: A hierarchical approach, Comp. Vision Graph. Image Proc., 36, 139-161, 1986.

Lyngsie, S. B., H. Thybo, and T. M. Rasmussen, Regional geological and tectonic structures of the North Sea area from potential field modelling, Tectonophysics, 413, 147-170, 2006.

Mallat, S. and S. Zhong, Characterization of signals from multiscale edges, IEEE Transactions on Pattern Recognition and Machine Intelligence, 14, 710-732, 1992.

McGrath, P. H., Dip and depth extent of density boundaries using horizontal derivatives of upward-continued gravity data, Geophysics, 56, 1533-1542, 1991.

Miller, H. G. and V. Singh, Potential field tilt- a new concept for location of potential field sources, J. Appl. Geophys., 32, 213-217, 1994.

Mirmehdi, M., G. A. W. West, and G. R. Dowling, Label inspection using the Hough transform on transputer networks, Microprocessors and Microsystems, 15(3), 167-173, 1991.

Moreau, F., D. Gibert, M. Holschneider, and G. Saracco, Wavelet analysis of potential fields, Inverse Problems, 13, 165-78, 1997.

Okay, A. I., A. Kaşlılar-Özcan, C. İmren, A. Boztepe-Güney, E. Demirbă̆, and İ. Kuşçu, Active faults and evolving strike-slip basins in the Marmara Sea, Northwest Turkey, a Multichannel Seismic Reflection Study, Tectonophysics, 321, 189-218, 2000.

Okay, A. I., O. Tüysüz, and Ş. Kaya, From transpression to transtension, changes in morphology and structure around a bend on the North Anatolian Fault in the Marmara region, Tectonophysics, 391, 259-282, 2004.

Okay, A. I., E. Özcan, W. Cavazza, N. Okay, and G. Less, Basement types, lower eocene series, upper eocene olistostromes and the initiation of the Southern Thrace Basin, NW Turkey, Turkish J. Earth Sci., 19, 1-25, 2010 .

Oruç, B. and A. Keskinsezer, Detection of causative bodies by normalized full gradient of aeromagnetic anomalies from East Marmara Region, NW Turkey, J. Appl. Geophys., 65, 39-49, 2008.

Oruç, B. and H. H. Selim, Interpretation of magnetic data in the Sinop area of mid Black Sea, Turkey, Using Tilt Derivative, Euler Deconvolution, and Discrete Wavelet Transform, J. Appl. Geophys., 74, 194-204, 2011.

Özcan, E., G. Y. Less, A. I. Okay, M. Baldi-Beke, K. Kollanyi, and I. Ö. Yılmaz, Stratigraphy and larger foraminifera of the eocene shallowmarine and olistostromal units of the southern part of the Thrace Basin, NW Turkey, Turkish J. Earth Sci., 19, 27-77, 2010.

Pawlowski, R. S., Use of slant stack for geologic or geophysical map lineament analysis, Geophysics, 62, 1774-1778, 1997.

Perinçek, D., Possible strand of the North Anatolian fault in the Thrace Basin, Turkey, an İnterpretation, Bull. Am. Assoc. Petrol. Geol., 75, 241257, 1991.

Princen, J., J. Illingworth, and J. Kittler, A hierarchical approach to line extraction based on the Hough transform, Comp. Vision Graph. Image Proc., 52, 57-77, 1990.

Sakınç, M., C. Yaltırak, and F. Y. Oktay, Palaeogeographical evolution of The Thrace Neogene Basin and The tethys-paratethys relations at northwestern Turkey (Thrace), Palaeogeogr. Palaeoclimat. Palaeoecol., 153, 17-40, 1999.

Şenel, H., Trakya (Ergene) Baseni-Hisarlıdă̆ resurgent kalderasının gravimetrik incelemesi ve jeotermal potansiyeli, Deprem Sempozyumu, Kocaeli, Turkey, 149-153, 2005.

Şengör, A. M. C., The North Anatolian Transform Fault: Its age, offset and tectonic significance, J. Geol. Soc. Lond., 136, 269-282, 1979.

Şengör, A. M. C., N. Görür, and F. Şaroğlu, Strike-Slip faulting and related basin formation in zones of tectonic escape, Turkey as a Case Study, edited by K. T. Biddle and N. Christie-Blick, Strike-Slip Deformation, Basin Formation, and Sedimentation, Soc. Econ. Paleontol. Mineral. Spec. Publ., 37, 227-264, 1985.

Şentürk, K. and C. Karaköse, Çanakkale Boğazı ve dolayının jeolojisi, Mineral Research and Exploration Institute, Report no. 371, Ankara, 207 p., 1987 (in Turkish).

Siyako, M., Trakya Bölgesi litostratigrafi birimleri, stratigrafi komitesi litostratigrafi birimleri serisi-2, Publication of the General Directorate of the Mineral Research and Exploration Institute of Turkey, 70 p., 2006 (in Turkish).
Siyako, M. and O. Huvaz, Eocene stratigraphic evolution of the thrace basin, Turkey, Sediment. Geol., 198, 75-91, 2007.

Sümengen, M. and I. Terlemez, Stratigraphy of the Eocene sediments from the southwestern Thrace, Bull. Miner. Res. Explor. Inst. Turkey, 113, 1730, 1991.

Sümengen, M., İ. Terlemez, K. Şentürk, and C. Karaköse, Stratigraphy, Sedimentology and tectonics of the Gelibolu Peninsula and Southwestern Thrace Basin, Mineral Research and Exploration Institute, Report no. 8128, Ankara, p. 146, 1987.

Ternek, Z., Geological study of the region of Keşan-Korudağ, Publication of the General Directorate of the Mineral Research and Exploration Institute of Turkey, D12, p. 78, 1949.

Trompat, H., F. Boschetti, and P. Hornby, Improved downward continuation of potential field data, Explor. Geophys., 34(4), 249-256, 2003.

Turgut, S. and G. Eseler, Sequence stratigraphy, tectonics and depositional history in Eastern Thrace Basin, NW Turkey, Mar. Petrol. Geol., 17, 61-100, 2000.

Turgut, S., M. Siyako, and A. Dilki, The geology and the petroleum prospects of the Thrace Basin, Proc. Geol. Congr. Turkey, 4, 35-46, 1983.

Turgut, S., M. Türkaslan, and D. Perinçek, Evolution of the Thrace Sedimentary Basin and Its hydrocarbon prospectivity, in Generation, Accumulation, and Production of Europe's Hydrocarbons, edited by A. M. Spencer, Oxford University Press, 415-437, 1991.

Tüysüz, O., A. Barka, and E. Yiğitbaş, Geology of the Saros graben and its implications for the evolution of the North Anatolian Fault in the Ganos-Saros region, Northwest Turkey, Tectonophysics, 293, 105-126, 1998.

Umut, M., M. İmik, Z. Kurt, I. Özcan, H. Sarıkaya, and G. Saraç, Tekirdağ, Silivri (İstanbul), Pınarhisar alanının jeolojisi, Mineral Research and Exploration Institute, Report No. 7349, Ankara, p. 76, 1983.

Umut, M., M. İmik, Z. Kurt, I. Özcan, M. Ateş, M. Karabıyıkoğlu, and G. Saraç, Edirne ili Kırklareli ili-Lüleburgaz (Kırklareli ili) Uzunköprü (Edirne ili) civarının jeolojisi, MTA Rap., 7604, p. 42, 1984.

Ünal, O. T., Trakya jeolojisi ve petrol imkanları, Turkish Petroleum Corporation, Report no. 391, Ankara, p. 80, 1967.

Ünay, E. and H. de Bruijn, On some neogene rodent assemblages from both sides of the dardanelles, Turkey, Newsletters on Stratigraphy, 13, 119-132, 1984.

Verduzco, B., J. D. Fairhead, C. M. Green, and C. MacKenzie, New insights into magnetic derivatives for structural mapping, The Leading Edge, 23(2), 116-119, 2004.

Wang, J. and P. J. Howarth, Use of the Hough transform in automated lineament detection, IEEE Transactions on Geoscience and Remote Sensing, 28, 561-566, 1990.

Wiladis, D., Automatic lineament detection using digital elevation models with second derivative filters, Photogramm. Eng. Rem. Sens., 65, 453458, 1999.

Yıldız, A., V. Toker, and I. Sengüler, The nannoplankton biostratigraphy of the middle Eocene-Oligocene units in southern Thrace Basin and the surface water temperature Variations, Turkish Assoc. Petrol. Geol. Bull., 9, 31-44, 1997.

Yunxuan, Z., Application of the radon transform to the processing of airborne geophysical data, Ph.D. thesis, Delft University of Technology, 1992.

Zeng, H., Q. Zhang, and J. Liu, Location of secondary faults from crosscorrelation of the second vertical derivative of gravity anomalies, Geophys. Prospect., 42, 841-854, 1994.

Zhang, L. L., T. Hao, J. Wu, and J. Wang, Application of image enhancement techniques to potential field data, Appl. Geophys., 2, 145-152, 2005.

Zhang, L. L., J. Wu, T. Hao, and J. Wang, Automatic lineament extraction from potential field images using the radon transform and gradient calculation, Geophysics, 71, J31-J40, 2006.

D. Aydogan (e-mail: aydogan@istanbul.edu.tr), A. Pinar, A. Elmas, O. Tarhan Bal, and S. Yuksel 